\title{
Socio-Economic Responsibility of Pharmaceutical Companies: Bangladesh Case
}

\author{
Nahid Akter \\ Lecturer, School of Business, Asian University of Bangladesh, Dhaka, BANGLADESH \\ *E-mail for correspondence: nahid116@gmail.com
}

https://doi.org/10.18034/abr.v8i3.165

\begin{abstract}
Bangladesh is a rustic of rising economy. The causes of its rising is high rate of industrialization and investment in different sectors. The pharmaceutical sector that is the second largest export earning source of the country after Ready Made Garments contributes almost 1\% of the GDP and is currently the third largest tax paying sector in the country. Square Pharmaceutical Limited (SPL) the biggest name in the pharmaceutical sector of Bangladesh has a market share of $19.3 \%$ and the total exporting amount become BDT 1,137.99 millions in FY 2016-2017 that is 34.46\% more than the previous year. This paper is almost done using the secondary data though a slight primary data is used where customer's choice is examined where the highest $38 \%$ of the customer like the brand name square. This study assessed and examined the role of pharmaceutical company to the economy of Bangladesh from the perspective of square pharmaceutical limited as the sample company. The researcher also investigates the corporate social responsibility activities played by the respective company. This paper will be useful to the pharmaceutical companies, concerned authorities, policy makers and the government to know the role of pharmaceutical sector and required initiatives to eliminate all the hindrances and resolve all the problems to make out pharmaceutical sector as a crucial actor in both domestic and international market.
\end{abstract}

Key words: Economy, Pharmaceutical, CSR, SPL, LDCs

\section{INTRODUCTION}

The economy of Bangladesh is moving forward every day at the back of our industries. It has constructed a solid base of the pharmaceutical area that is the second one biggest export incomes source of country after Ready Made garments and this strong base is taken into consideration to come to be a capability sector in the approaching days to aid our economy. Prior to the Liberation battle of 1971 there has been in frequently any pharmaceutical enterprise in Bangladesh, even after the liberation struggle the new government could not allot sufficient price range for fitness sector. After the annunciation of Drug manipulates Ordinance -1982, the pharmaceutical sector began to enlarge vertically.

In keeping with the Directorate preferred of Drug management (DGDA), the marketplace percentage of the domestically produced drug changed into175 crore in 1981 that improved to 325 crore with the aid of 1985. Many years after its emergence Bangladesh is now placed to end up a main exporter of pharmaceutical products. Skillful attitudes, expertise and progressive thoughts from the specialists have been the key reasons why this enterprise grew within the manner it did. After Nineteen Nineties, some of the agencies started producing insulin, hormones and cancer preventing pills the ones were now not formerly produced in the country. The modern-day nearby pharmaceutical market length of Bangladesh is expected to be approximate Tk. 1.3 Billion USD and the yearly growth price emerge as $11.36 \%$ that became about $8.12 \%$ in 2013 . The Pharmaceutical industry of Bangladesh is now selfcontained in pleasurable the local. The yearly average boom price of prescribed drugs has hit double digit considering 2009. Pharmaceutical groups satisfy greater than ninety $7 \%$ of nearby call for of medicines and about 30 companies export a good sized amount of drugs to 107 countries, along with Germany, USA, France, Italy, united kingdom, Canada, Netherlands and Denmark. There are approximately 250 organizations energetic in the marketplace for the time being. This rapidly developing enterprise contributes nearly $1 \%$ of the GDP and is presently the third biggest tax paying region within the USA. Its Tk. four billion $(\$ 51.7 \mathrm{~m})$ in pharmaceutical export 
profits pales in comparison to the $\$ 20$ billion the country makes from readymade garment exports. However the region's increase is outstanding given the reality those two decades in the past, seventy five \% of Bangladesh's pharmaceutical merchandise had been imported. In keeping with international marketing offerings (IMS), Bangladesh's home pharmaceuticals market grew nearly thirteen \% to $\$ 250 \mathrm{~m}$ in 2013. Pharmaceutical exports from Bangladesh rose 15.sixty five percent year-on-yr to Tk 553.3 crore in monetary 2016-17, riding on the returned of developing international demand, high great products and competitive fees. There are about 450 generics registered in Bangladesh. Out of those 450 generics, 117 are within the controlled category i.e. within the critical drug list. The last 333 generics are in the decontrolled category; the total wide variety of manufacturers or gadgets which are registered in Bangladesh is presently envisioned to be 537 even as the full quantity of dosage bureaucracy and strengths are 830 . Bangladesh pharmaceutical industry is specially ruled by means of home manufacturers. Of the total pharmaceutical marketplace of Bangladesh, the local businesses are taking part in a market proportion accomplish in around $80 \%$, even as the MNCs are having a marketplace percentage of $20 \%$. Out of the top ten pharmaceutical agencies in Bangladesh, 8 are nearby pharmaceutical groups; at the same time as most effective are MNCs. The pharmaceutical quarter has already been declared as the thrust zone by means of the government of Bangladesh.

The leading pharmaceutical organizations in Bangladesh are rectangular prescription drugs, Beximco Pharma, Incepta Pharma, Opsonin Pharma and ESkayef Bangladesh. Square and Beximco have a blended market proportion of $20 \%$. The corporations in most cases produce capsules against AIDS, diabetes, bronchial asthma, cancer and various different sicknesses. The most important call within the pharmaceutical area of Bangladesh is square prescription drugs constrained (SPL). It has a market percentage of $93 \%$. Incepta Pharmaceutical and Beximco prescribed drugs respectively have $8.5 \%$ and $7.6 \%$ market share. Its journey to the increase and prosperity has been no bed of roses. From the inception in 1958, it has nowadays burgeoned into one of the top line conglomerates in Bangladesh. Square prescription drugs Ltd., the flagship corporation, is maintaining the strong leadership role in the pharmaceutical industry of Bangladesh due to the fact that 1985 and is now on its manner to becoming a excessive overall performance international participant.

The marketplace length, marketplace share and boom of rectangular pharmaceuticals Ltd are BDT 19,722,066,693, $19.4 \%$ and $25.36 \%$ respectively where the second one function maintaining employer call Incepta Pharma in the country display the consequences of marketplace size, market share and boom are BDT 10,184,993,624, 10.02\% and $11.84 \%$ respectively. The Chemical department of square started business production in 1995. From the year 1997 it started out its complete-fledged production and advertising to all top prescribed drugs within the country together with Aventis Pharma, Novartis Bangladesh Ltd., Glaxo Smith Kline, ACI Ltd., Reckitt \& Colman, Beximco prescription drugs Ltd., The ACME Laboratories Ltd, Eskayf Bangladesh Ltd., Opsonin chemicals, Renata Ltd., important pills Co. Ltd. and so on with accurate reputation and loyalty. Square commenced exporting finished pharmaceutical formulations considering the fact that 1987 . Square gives more than 200 molecules in over 350 formulations, from its 2 WHO GMPcompliant production plant life. As popularity to its export contribution to countrywide financial system, square received the country wide Export Trophy in 1997. To bolster its international operation in addition, rectangular is planning to go into in Russian Pharma marketplace thinking about market potentiality. To preserve the changing environment SPL made convert itself into Public constrained enterprise in 1991.

With an incredible music document SPL became the first enterprise in Bangladesh to move the Billion Taka mark turnover in 1992. In 1994 SPL got its share listed within the Dhaka and Chittagong inventory Exchanges. Authorized Capital towered to billion taka and paid up capital through now could be taka 250 million. Currently square is circle of relatives of 1321 participants. It has scaled-up CSR sports to do not forget the hobbies of our external \& internal stakeholders like customers, personnel, providers, shareholders, society, government and many others and ecological \& ethical considerations in all factors of operations. Square herbal \& Nutraceuticals Ltd. (SHNL) has been presented the "Asia responsible Entrepreneurship Awards 2014-South Asia" beneath the class of 'Social Empowerment Award'. The Asia responsible Entrepreneurship Awards is a nearby reputation Award organized by using business enterprise Asia to honor groups for super, innovative and global elegance products, offerings, projects and applications. Those packages reveal the organization's management, sincerity and on-going commitment in incorporating responsible and ethical values, criminal compliance, issues for fitness issues, respect for humans and people, involvement in groups and protection of the surroundings into the way they run their employer. The take a look at tries to cope with function of square pharmaceutical restricted from the monetary and social duty viewpoints that contributing the country in view that long term.

\section{LITERATURE REVIEW}

Review of literature is an integral part of conducting a research. This is necessary to find out the research gap in the proposed field of the study. The researcher has reviewed some related literatures in order to find out research gap regarding the role of square pharmaceutical limited in Bangladesh. It clarifies that different authors have conducted research on different topics, but not a single research has been conducted on the present titled of 
this study. In this study the researcher readout some books, journals, newspapers and published papers which are very much helpful to identify the overall role of pharmaceutical industries to the economy of Bangladesh particularly the role of Square Pharmaceutical Limited.

Anesary et al. (2014) opined that the pharmaceutical enterprise in Bangladesh is one of the most advanced hitech sectors in Bangladesh Economy. Bangladesh pharmaceutical industry is specially ruled through domestic manufacturers. Particularly Square pharmaceuticals retained the pinnacle role with its local income achieving Tk 19.72 billion in 2017 inside the country's Tk 101 billion pharmaceutical market followed by Incepta Pharmaceuticals company. Ishika (2010) highlighted that Squarer Pharmaceuticals Limited (SPL) is the biggest pharmaceutical organization in Bangladesh and it has been continuously in the1st place amongst all countrywide and multinational agencies seeing that1985.It was established in 1958 and being transformed into a public limited corporation in 1991. Akter (2015) mentioned that the financial system of Bangladesh is shifting ahead each day on the returned of our industries.

Apart from the fabric and garments industry that accommodates maximum of the employment and export proportion, there are other industries which might be supporting the financial system and providing a balance via import substitution. These industries have great capability to flourish and as a country is inching in the direction of a middle-income popularity, they have got loads to provide to the financial system. Mazumder (2015) point out that during the mid-1970s (1975) SPL entered into a technical collaboration agreement with Janssen pharmaceuticals, Belgium, which is a subsidiary of Johnson and Johnson international, USA. Since that its inception SPL practices accurate manufacturing Practices (GMP), as endorsed via the arena health agency (WHO), SPL's growth was now not being stunted. In 1982, turnover reached over Tk. 240 million, and the payroll extended 400 heads, and with the aid of 1988 SPL's turnover exceeded $1 / 2$ a billion taka., and the range of employees to 750. At gift SPL is exporting its products to Nepal, Myanmar, Pakistan, SriLanka, Cambodia, and Russia.

\section{RATIONALE OF THE STUDY}

The pharmaceutical sector has emerged as one of the fastest growing business sector in present Bangladesh. It is the second highest contributors to our national exchequer, and it is the largest white collar labor intensive employment sector. The present study is aimed at role of square pharmaceutical limited in Bangladesh. It is done on the basis of self-effort and the data collected from different sources. Obviously this study will enhance the level of knowing of us about the economic and social responsibilities played by square pharmaceutical limited and will help us to apply the knowledge in other sectors. It will also help to develop the efficiency of the concerned authority and the policy makers of the pharmaceutical sectors.

\section{ObJective OF the Study}

The main objective of this study is to review the role of square pharmaceutical limited to the economy and society of Bangladesh. The study is also designed to achieve the following objectives:

- To assess the comparative financial performance of square pharmaceutical limited over the study period.

- To investigate the contribution of pharmaceutical companies to the national economy of Bangladesh.

- To make the recommendations for the sound role management in future of the pharmaceutical industries in Bangladesh.

\section{MATERIALS AND MethodS}

The study is quantitative in nature. The present study is conducted mainly on the basis of secondary data and it is concerned with pharmaceutical sector of Bangladesh. To conduct this study the researcher has taken square pharmaceutical limited as the sample company from pharmaceutical sectors of Bangladesh. This research also conducted a small survey over the customer of pharmaceutical product and their choices. The sample was taken from different hospitals and pharmacy that came to buy the products. On the basis of availability of data, accuracy of data, time span and cost factor of the study, secondary data play a significant role in research (Sekaran, U., 2002). Data has been collected from the published research papers, different books, dissertations, assignment or internship reports, annual reports of the company and newspapers concerning the study. The data has been analyzed on the first hand collection presented and analyzed through simple statistical tools such as charts, tables, percentages which show the corresponding years.

\section{LIMITATION OF THE STUDY}

The limitation of this study is that this study did not use optimum primary data rather a slight respondent are interviewed from different hospitals and pharmacy only to investigate the percentage of choice of buying the product of respective company. This study did not use the modern statistical tools to analyze the collected data. Despite these limitations, the collected data have been processed manually and present form has been prepared in order to make the study more informative, analytical and useful for the users.

\section{RESEARCH RESULTS AND FINDINGS}

The collected data of the square pharmaceutical limited has been analyzed from different perspective to know its role towards the economy of Bangladesh. 
Table 1: Market Growth Trend

\begin{tabular}{|c|c|c|}
\hline Year & $\begin{array}{c}\text { National Market } \\
\text { Growth Rate }\end{array}$ & $\begin{array}{c}\text { Company's } \\
\text { Growth Rate }\end{array}$ \\
\hline 2013 & $23.80 \%$ & $17.53 \%$ \\
\hline 2014 & $22.30 \%$ & $19.17 \%$ \\
\hline 2015 & $11.91 \%$ & $11.87 \%$ \\
\hline 2016 & $8.12 \%$ & $16.43 \%$ \\
\hline 2017 & $11.36 \%$ & $25.36 \%$ \\
\hline
\end{tabular}

Source: IMS Report, 2017

The growth trend shows in table 1 indicating positive outlook. The growth of the economy at $6.12 \%$ of Bangladesh during the fiscal year 2016-17 and its allevation to the lower-middle income group of nations from that of LDCs. The outlook of the table 1 of National Market Growth Rate and Company's Growth Rate shows the contribution of square pharmaceutical limited to the economy of Bangladesh where table shows in 2014 National Market Growth Rate is $11.36 \%$ but SPL made the growth of $25.36 \%$ such situation offers scope for further growth in investment for expansion in this sector and the upwards economic growth of the country.

Table 2: Contribution to National Exchequer

\begin{tabular}{|c|c|c|}
\hline $\begin{array}{c}\text { Fiscal } \\
\text { Year }\end{array}$ & $\begin{array}{c}\text { Amount } \\
\text { (BDT) }\end{array}$ & $\begin{array}{c}\text { \% of Sales } \\
\text { Revenue (Net) }\end{array}$ \\
\hline $2015-2016$ & $5,113,387,771$ & 24.09 \\
\hline $2016-2017$ & $6,314,740,042$ & 24.45 \\
\hline
\end{tabular}

Source: Annual Report, 2016-2017

The above table shows that the SPL contributed a huge amount with significant percentage of sales revenue to the National Exchequer other than any other respective companies in Bangladesh. And its historical contribution to the National Exchequer is upwards trends following. As well the contribution constitutes $24.45 \%$ of the sales revenue in $2016-17$ as against $24.09 \%$ in the previous year of $2015-2016$.

Table 3: Operating Financial Results

\begin{tabular}{|c|c|c|c|}
\hline Particulars & $\begin{array}{c}\mathbf{2 0 1 6 - 2 0 1 7} \\
\text { (BDT) }\end{array}$ & $\begin{array}{c}\mathbf{2 0 1 5 - 2 0 1 6} \\
\text { (BDT) }\end{array}$ & $\begin{array}{c}\mathbf{\%} \\
\text { Increase }\end{array}$ \\
\hline Gross Turnover & $30,281,713,746$ & $24,193,356,807$ & $25.17 \%$ \\
\hline Net Turnover & $26,212,862,068$ & $20,910,773,826$ & $25.36 \%$ \\
\hline Gross Profit & $11,841,989,969$ & $9,182,781,155$ & $28.96 \%$ \\
\hline Net Profit (BT) & $7,595,901,234$ & $5,504,459,836$ & $38.00 \%$ \\
\hline Provision for Taxation & $1,679,877,193$ & $1,329,682,520$ & $26.34 \%$ \\
\hline Net Profit (AT) & $5,743,623,832$ & $4,031,811,286$ & $42.46 \%$ \\
\hline
\end{tabular}

Source: Annual Report, 2014-2015

The table no 3 indicating the operating financial performance of square pharmaceutical limited during the consecutive two fiscal years where the net profit after tax has been increased at $42.46 \%$ than its previous year. Such showdown of increase of net profit is indicating the role of square pharmaceutical limited to the economy of the country and the public as well. The contribution to the government of square pharmaceutical limited can be easily understand by using the information of provision for taxation that is $26.34 \%$ more than the preceding years of 2017.
Table 4: Financial Outcomes

\begin{tabular}{|c|c|c|c|}
\hline Particulars & $\mathbf{2 0 1 6 - 2 0 1 7}$ & $\mathbf{2 0 1 5 - 2 0 1 6}$ & $\begin{array}{c}\% \\
\text { Increase }\end{array}$ \\
\hline Gross Margin (Net Turnover) & $45.17 \%$ & $43.91 \%$ & $2.87 \%$ \\
\hline Net Margin (BT) & $28.98 \%$ & $26.32 \%$ & $10.11 \%$ \\
\hline Net Margin (AT) & $21.91 \%$ & $19.28 \%$ & $13.64 \%$ \\
\hline $\begin{array}{c}\text { Earnings Per Share (EPS) } \\
\text { (BDT) }\end{array}$ & 10.36 & 7.27 & $42.50 \%$ \\
\hline EPS on IPO & 574.36 & 403.18 & $42.46 \%$ \\
\hline $\begin{array}{c}\text { Consolidated Earnings Per } \\
\text { Share (EPS) (BDT) }\end{array}$ & 10.80 & 8.92 & $21.08 \%$ \\
\hline
\end{tabular}

Source: Annual Report, 2014-2015

The earnings per share towards the common stock holders of the fiscal year 2016-2017 become BDT 10.36 that is $42.50 \%$ more than the previous year of 2015-2016 is indicated by the table 4. As well the consolidated earnings per share in the fiscal year become BDT 10.80 that is $21.08 \%$ more than the previous year. The entire information of the table 4 focusing about the contribution of square pharmaceutical limited towards the economy and people of Bangladesh.

Figure 1: Value Added Statement

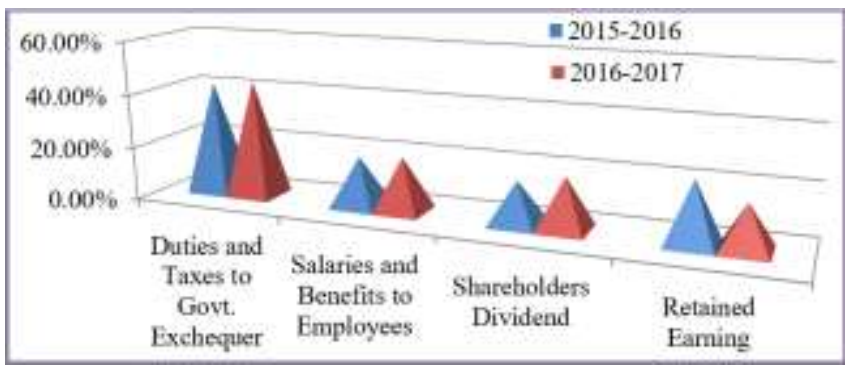

Source: Annual Report, 2014-2015

The above graph shows the value added statement during the two consecutive fiscal years of 2015-16 \& 2016-17 where the contributing forces are shown as duties and taxes to govt. exchequer which have the increasing trends. The contribution towards the employees has also been increased, the stockholders are receiving more dividends and only the pyramids bar of 2016-2017 is showing the downwards direction in case of retained earning that is another good sign for the economy and people of the country.

Figure 2: Graphical Presentations of Historic Turnover and Its Growth

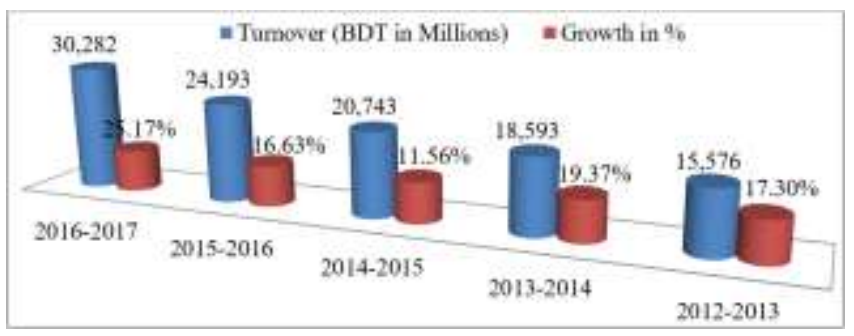

Source: Annual Report, 2016-2017

The turnover and its historic growth over the five years periods of square pharmaceutical limited is shown in the 
figure no 2 . The highest growth of $25.17 \%$ is seen in the current year with the turnover of BDT 30,282 millions and that growth is $8 \%$ more than the initial period of the study that is 2013-2014. This figure also indicating the amount of turnover of current is almost BDT 10,000 millions more than the initial period of the study.

Figure 3: Graphical Presentations of Historic Net Profit (AT) and Its Growth

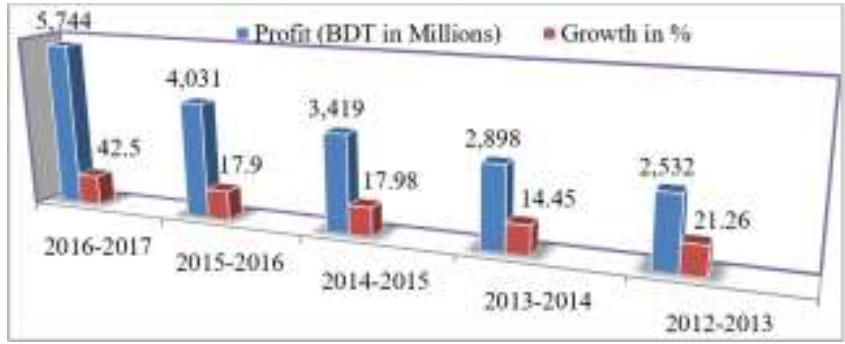

Source: Annual Report, 2016-2017

The figure no 3 that is presenting of historic net profit (After Tax) and its growth of square pharmaceutical limited focusing the contribution towards the economy and people of Bangladesh as the profit is almost distributed to the public of the country. More than five and half thousand millions BDT has been made as net profit with the growth rate of $42.5 \%$ in the FY 20162017that is more than double figure than those of FY 20122013. This picture is strongly showed about the role and contribution of square pharmaceutical limited.

As a dominant and the biggest name in the pharmaceutical sector of Bangladesh square pharmaceutical is playing a vital role to the society of the country as the activities of CSR where corporate social responsibility (CSR) is the continuing commitment by business to behave ethically and contribute to economic development while improving the quality of life of the workforce and their families as well as of the local community and society at large.

The first and significant corporate social responsibility is played by square pharmaceutical limited is determined and committed to safeguard public health of the country by providing quality product that is operating $24 / 7$ free helpline termed as Supermom is a free telephone (+880 961 2222 333) service and a full-fledged interactive Bengali website (www.supermombd.com) for mothers and their babies for the purpose healthy family. Square Toiletries Limited is doing their responsibility as the part of society by educating 1.5 million girls regarding adolescent health \& hygiene, ensuring a healthy future for 3.3 millions babies and a healthy future for 1.6 millions girls. Through direct outbound phone call, SMS blast, product pack communication, Square Toiletries Ltd. attempted to make mothers aware about the importance of breast feeding and vaccination that is helping to ensure the future of 3.3 million babies and help eliminate polio from Bangladesh as well. Square is partnering one of the projects of CARE the organization of ' $J \mathbf{I C A}$ ', through this project it is ensured empowerment of rural women as they can earn money by purchasing its products at trade price \& by selling those products to rural households at maximum retail price (MRP) and also ensure basic health \& hygiene to the rural area by the sales women in explaining the necessity of using sanitary napkin and health soaps and making these products available at their doorsteps. It supplies customized government medicine as per the requirement of Bangladesh government. Moreover, in times of epidemics and disasters it is always beside the government with its expanded helping hands. It is also conducting transparent business operations based on market mechanism within the legal, ethical \& social framework that enables the management to ensure highest degree of both financial and behavioral accountability. For the betterment of the employees, it follows the updated and latest labor policies and laws that encourage work environment for making non-discrimination \& fair treatment policy both in the recruitment \& selection process and performance management system. As the activity of corporate social responsibility Square pharmaceutical limited helps many NGO's in their effort to make available healthcare to the disadvantage population of the country. It sponsors programs to build awareness on the healthcare need. Square pharmaceutical limited is making its significant role in the education sector of the country that it is constructed both Kindergarten and high school to facilitate quality education to the children of the employees in the northern zone Pabna of the country that a $100 \%$ 'not- forprofit' initiative where the students receive quality education at a very subsidized fee. Other than its own employees' children, it also provides this education facility for the children of local community. The company maintains a high standard of pollution free environment as per GMP Regulations or WHO standards or the government laws. Moreover, square pharmaceutical limited takes multiple initiatives through healthcare publications, seminars \& clinical meetings like Continual Medical Education (CME) program building awareness about the health care of the poor people. It is also building the awareness program for the rights of physically-challenged people. Besides these square pharmaceutical limited arranges road safety campaign \& road side shade and making donation to hospitals, medical colleges, local community \& underprivileged people.

\section{Conclusion And Recommendation}

The pharmaceutical industries in Bangladesh are gifted with unparalleled potential to grow in the days ahead as they enjoy a number of competitive advantages. The industry's ability to comply with guidelines of quality assurance has put it on a solid base. Almost all companies are equipped with World Health Organization (WHO) Good Manufacturing Practice (GMP) standards.

It has the ability to face competition from developing countries like India, China, Brazil and Turkey in its export markets due to strict quality compliance. As the leading 
company in the pharmaceutical world of Bangladesh square pharmaceutical limited is playing a vital role to the economy of the country and it also contributing to the society as the CSR activities that is assessed and investigated in this paper. From the study the role of square pharmaceutical limited to the both domestic and international pharmaceutical sector is examined and seen. Though square pharmaceutical limited is contributing to the country from both economic and social perspective, but the research chalk out some recommendations those should be consider by the pharmaceutical companies, the respective authorities and the government of the country as well, such as:

- The concerned company and the authority should be conscious about the laboratory because the laboratory facilities are still not up to date. To maintain the quality of the medicines drug control authority of Bangladesh should set up laboratories with modern testing equipment.

- There should be taken care of the exporting procedure and facilities because the customs authority of Bangladesh has some strict rules and regulation in case of sending drug samples to importing countries. Because of these restrictions the pharmaceutical companies are losing international market as they can't send sufficient amount of samples to the buyers.

- The researcher thinks that the regulatory authorities of USA, EU, Australia, Japan and other highly regulated and semi regulated countries have strict regulation in registering pharmaceutical products. Regulatory markets have their own criteria like hightech manufacturing plant, standard manufacturing process, accurate quality control and highly skilled employees but most of the companies of Bangladesh are unable to meet these criteria.

- The researchers also found that every year the medicine manufacturing companies recruit medical representatives but they can hardly affect the market as they lack proper training and professionalism. Because of having no sufficient incentives in comparison with their effort, the turnover rate of medical representatives is very high. Current political turbulence and bureaucratic obstacles are hampering the export of pharmaceutical products.

- Besides those, the researcher recommend that there are some principles for the manufacture of medicines and APIs (Active Pharmaceutical Ingredients), these principles are known as Good Manufacturing Practice (GMP) or current Good Manufacturing Practice (cGMP) and it is also one of the requirements of regulatory markets.

- The government should offer more incentives to those who invest in the API industries. If this is ensured, a growth rate of $80 \%$ can be expected in the coming years.
- Moreover, the researcher pointed out that the drug manufacturers, on their part, should make efforts to drive out counterfeit drugs and medicines from the market. As well the government, on its part, should launch drives on a continuous basis against counterfeit and spurious drugs by strengthening the Drug Administration

From this study the researcher come into the point that Square Pharmaceuticals Limited the pharmaceutical giant in the country, is a trusted name in the industry of manufacturing quality medicines for more than four decade with the growth of turnover came the increase in number of employees. The government should really be attentive to remove all the obstacles and solve all the problems to see pharmaceutical sector as a vital player in both domestic and international market.

\section{REFERENCES}

Akter, M.K. (2015). The pharmaceuticals industry of Bangladesh, Journal of Economics, Independent University, Vol. 08, Issue 04 .

Anesary, M.A.W., Hossain, M. J., Mamun, M.R.A., Salam, M.G.A., Rahman, K. S., Morshed, M. M., Rahman, M. M., Akter, S., Waheduzzaman, M., Kabir, Z. M., Hassan, S., Laboni, S., Hossain, M. I. (2014), Pharmaceutical sector of Bangladesh: prospects and challenges, Internship Report, MBA (BRAC Business School), Retrieved September 4, 2018. URI: http:/ /hdl.handle.net/10361/3220

Annual Report, Square Pharmaceutical Limited, 2014-2015, August, 2015.

Faroque, B.M. (2011). Biomedical consideration in the manufacture, clinical trial and bioequivalence studies of pharmaceuticals, Bangladesh Journal of Bioethics 2011 Vol. 2 Issue 1 Pp. 18-21.

Ishika, M. A. (2010). Trend analysis of generic shifting in the Bangladesh pharmaceutical market (2006-2010) employee organization: square pharmaceuticals ltd Bangladesh, BRAC School of Business, BRAC University, Bangladesh.

Islam, S., Rahman, A., \& Mahmood, A. (2018). Bangladesh Pharmaceutical Industry: Perspective and the Prospects. Bangladesh Journal of Medical Science, 17(4), 519525. doi: http://dx.doi.org/10.3329/bjms.v17i4.38306

Mazumder P.M. (2015), Recruitment \& selection process of Square Pharmaceuticals Ltd., Internship Report, BBA (BRAC Business School), Retrieved September 5, 2018, URI: http://hdl.handle.net/10361/4134.

Sekaran, U. (2002) Research Methods for Business, John Wiley \& Sons, Inc.: USA.

Sultana, J. (2016). Future Prospects and Barriers of Pharmaceutical Industries in Bangladesh. Bangladesh Pharmaceutical Journal, 19(1), 53-57. doi: http:/ /dx.doi.org/10.3329/bpj.v19i1.29239

$--0-$

Online Archive: https://abc.us.org/ojs/index.php/abr/issue/archive 